\title{
GLUCOSE UTILIZATION BY SPERMATOZOA OF THE DOMESTIC COCK AS INFLUENCED BY OVIDUCAL EXTRACTS FROM HENS MAINTAINED UNDER DIFFERENT ENVIRONMENTAL TEMPERATURES
}

\author{
B. HOWARTH, JR AND T. M. HUSTON \\ Department of Poultry Science, University of Georgia, Athens, Georgia 30602, U.S.A.
}

(Received 30th Fuly 1973)

\begin{abstract}
Summary. Utilization in vitro of $\left[\mathrm{U}-{ }^{14} \mathrm{C}\right]$ glucose by spermatozoa of the domestic fowl, Gallus domesticus, in the presence of oviducal extracts from hens maintained under two environmental temperatures $\left(19^{\circ}\right.$ and $\left.31^{\circ} \mathrm{C}\right)$ was determined by radiorespirometry. It was found to be significantly greater in the presence of extracts obtained from the infundibulum than in any of the other extracts evaluated. Unlike those of other regions of the oviduct, extracts from the isthmus decreased glucose utilization by the spermatozoa. Extracts obtained from hens maintained at $31^{\circ} \mathrm{C}$ consistently had a greater stimulatory effect on glucose utilization by the spermatozoa (regardless of the source of the extract) as compared to extracts from hens maintained at $19^{\circ} \mathrm{C}$.
\end{abstract}

\section{INTRODUCTION}

Available evidence (Huston \& Carmon, 1958; Glark \& Sarakoon, 1967; Martin, 1970) indicates that high environmental temperatures have a more pronounced effect upon the reproductive ability of the female than of the male fowl.

Huston \& Carmon (1958) reported that the fertility of eggs from hens maintained at normal variable temperatures was significantly higher than that of hens maintained at high $\left(32^{\circ} \mathrm{C}\right)$ environmental temperatures. There were no statistically significant differences in fertility between cocks maintained at high $\left(32^{\circ} \mathrm{C}\right)$ temperatures and those maintained at normal variable temperatures. Since pooled semen samples were used for insemination, it is possible (Boone \& Huston, 1963) that two or three superior males may have fertilized most of the eggs and obscured the lower fertility of other males in the group exposed to the high temperature.

Clark \& Sarakoon (1967) reported that fertility rates for females maintained in a variable environment $\left(21^{\circ}\right.$ to $\left.38^{\circ} \mathrm{C}\right)$ averaged approximately $13 \%$ less than females at $20^{\circ} \mathrm{C}$. By contrast, no significant differences were found between initial fertility rates for males maintained under similar environmental conditions. The fertility of eggs from hens maintained at $30^{\circ} \mathrm{C}$ was reported by Martin (1970) to be consistently lower than that from hens maintained at 
$8^{\circ} \mathrm{C}(68.9 \%$ versus $83.1 \%$, respectively). The average fertility for males maintained at $30^{\circ}$ and $8^{\circ} \mathrm{C}$ was $75.1 \%$ and $76.9 \%$, respectively.

The physiological mechanism(s) responsible for the decline in the fertility of hens exposed to high temperature have not been demonstrated. As a working hypothesis, an assumption was made that the decline in fertility could be at least partly due to a defective oviducal environment which might be reflected in the metabolic activity of spermatozoa. In this study, a sensitive radiorespirometric procedure was used to measure the utilization in vitro of carbon14 uniformly labelled glucose ([U- $\left.{ }^{14} \mathrm{C}\right]$ glucose) by cock spermatozoa in the presence of oviducal extracts from hens maintained under different environmental temperatures.

\section{MATERIALS AND METHODS}

Ten Athens random-bred hens, maintained from 1 day of age in each of two different environmental chambers with mean temperatures of $19^{\circ}$ or $31^{\circ} \mathrm{C}$, respectively, were used to obtain oviducal extracts. The experiment was replicated ten times, each replicate consisting of one hen from each environment. Hens in seven of the replicates at the time of autopsy had recently laid eggs. Their oviducts were either empty or contained an ovum in the infundibulum or upper magnum. Oviducts from hens in the remaining three replicates contained an egg in the uterus. Due to the small number of hens in the latter category, no attempt was made to account for the stage of the egg-laying cycle in the analysis of the data.

A constant amount of tissue $(300 \mathrm{mg}$ ) from each region of the oviduct of each hen (vagina, uterovaginal junction, uterus, isthmus, magnum, and infundibulum) was weighed, and ground in $1.5 \mathrm{ml}$ modified Krebs-Ringer bicarbonate buffer (MKRBB), $\mathrm{pH} 7 \cdot 40$, using a $10-\mathrm{ml}$ borosilicate glass vessel and motor-driven teflon pestle. The homogenate was then filtered through glass wool to remove tissue particles. All processing of oviducal tissue was carried out at $5^{\circ} \mathrm{C}$ in an ice-bath.

Pooled semen samples were collected by the method of Burrows \& Quinn (1937) from White Rock males approximately $15 \mathrm{~min}$ before the start of incubation. The males used were maintained at a mean temperature of $19^{\circ} \mathrm{C}$.

Semen ampoules (Text-fig. 1) containing $0.05 \mathrm{ml} \mathrm{MKRBB,} 10$ i.u. penicillin and $0.5 \mu \mathrm{Ci}\left[\mathrm{U}-{ }^{14} \mathrm{C}\right]$ glucose were filled, sealed and stored at $-20^{\circ} \mathrm{C}$ until incubation. The specific activity of $\left[\mathrm{U}-{ }^{14} \mathrm{C}\right]$ glucose was $223 \mu \mathrm{Ci}$ per $\mu \mathrm{mol}$. Immediately preceding incubation in vitro, $0.1 \mathrm{ml}$ oviducal extract and $20 \mu \mathrm{l}$ semen were added to each ampoule. Ampoules were prepared in duplicate for each extract from each of the two hens per replicate. As each replicate of the experiment was conducted on a separate day, sperm concentrations ranged between 4.8 and $16 \times 10^{6}$ spermatozoa per $20 \mu \mathrm{l}$. Ampoules within each replicate contained the same concentration of spermatozoa. In addition to the ampoules containing the oviducal extracts, four additional ampoules and their duplicates were prepared as controls for each replicate, and were referred to as C-1, C-2, C-3 and C-4. In addition to the amounts of MKRBB, penicillin and $\left[\mathrm{U}-{ }^{14} \mathrm{C}\right]-$ glucose contained within each ampoule, $0.12 \mathrm{ml} \mathrm{MKRBB}$ was added to $\mathrm{G}-1$; 
$20 \mu \mathrm{l}$ MKRBB plus $0 \cdot 1 \mathrm{ml}$ pooled oviducal extract obtained from the hen maintained at $19^{\circ} \mathrm{C}$ was added to $\mathrm{C}-2 ; 20 \mu \mathrm{l}$ of MKRBB plus $0.1 \mathrm{ml}$ pooled oviducal extract obtained from the hen maintained at $31^{\circ} \mathrm{G}$ was added to $\mathrm{C}-3$; and $0.1 \mathrm{ml}$ MKRBB plus $20 \mu \mathrm{l}$ pooled semen was added to $\mathrm{C}-4$ (no extract).

After the appropriate additions, each ampoule was flushed with a gas mixture of $3 \% \mathrm{CO}_{2}, 20 \% \mathrm{O}_{2}$ and $77 \% \mathrm{~N}_{2}$. This was followed by the attachment of a tygon connector fitted with a replaceable glass bulb (Text-fig. 1) which contained a piece of filter-paper soaked in $0.1 \mathrm{ml}$ diethanolamine buffer prepared to maintain a $3 \% \mathrm{CO}_{2}$ atmosphere (Pardee, 1949). Hourly collections of $\mathrm{CO}_{2}$ were made during a 2-hr incubation at $41^{\circ} \mathrm{C}$, after which the residual $\mathrm{CO}_{2}$ was collected upon addition of sulphuric acid. After being replaced, the $\mathrm{CO}_{2}$-containing glass bulbs were put into $10 \mathrm{ml}$ scintillation fluid (Buhler, 1962 ) and counted in a liquid scintillation spectrometer. The amount of

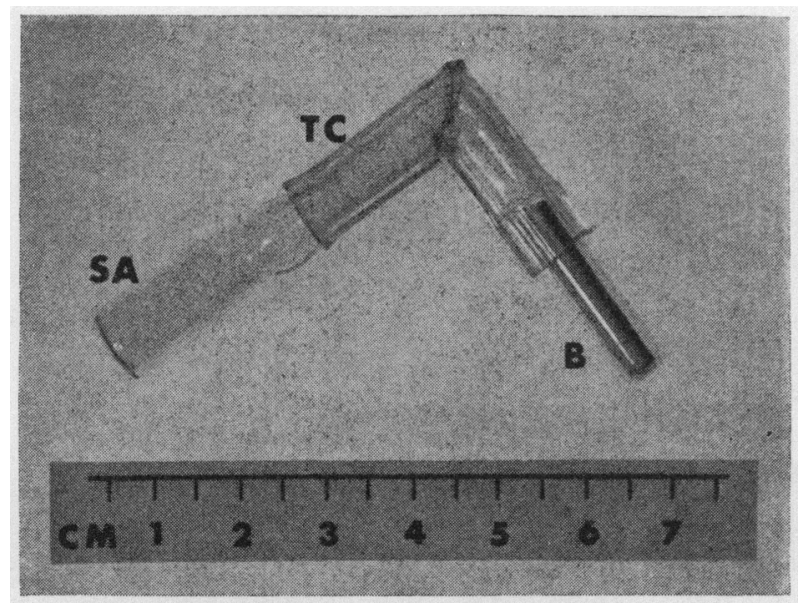

Text-Fig. 1. Ampoule system used for culture of spermatozoa. The semen ampoule (SA) is connected to a replaceable glass bulb (B) by means of a tygon connector (TC).

substrate metabolized to $\mathrm{CO}_{2}$ per $1 \times 10^{6}$ spermatozoa was calculated after adjustment for counting efficiency $(85 \%)$ and background (G-1). The data were analysed by least squares analysis and Kramer's modification of Duncan's multiple range test.

\section{RESULTS}

The amounts of $\left[\mathrm{U}-{ }^{14} \mathrm{C}\right]$ glucose utilized per $10^{6}$ spermatozoa over a 2-hr period in the presence of various oviducal extracts obtained from hens maintained under two environmental temperatures $\left(19^{\circ}\right.$ and $\left.31^{\circ} \mathrm{C}\right)$ are shown in Text-fig. 2. Significant effects of temperature $(P \leqslant 0.05)$ and oviducal extract $(P \leqslant 0.01)$ on glucose utilization by cock spermatozoa were observed. Extracts obtained from hens maintained at $31^{\circ} \mathrm{C}$ consistently had a greater stimulatory effect on glucose utilization by cock spermatozoa (regardless of the area of oviduct extracted) as compared to extracts from hens maintained at $19^{\circ} \mathrm{C}$. 
Infundibular extracts from hens within each of the two temperature groups significantly $(P \leqslant 0 \cdot 01)$ stimulated a greater glucose utilization by cock spermatozoa than any of the other extracts evaluated, including spermatozoa incubated in the absence of oviducal extracts (C-4). The mean glucose utilization by spermatozoa in the presence of infundibular extracts obtained from hens maintained at $31^{\circ} \mathrm{C}$ was more than double that observed from spermatozoa in the presence of infundibular extracts obtained from hens maintained at $19^{\circ} \mathrm{C}$. Compared to glucose utilization by spermatozoa in the absence of oviducal extract (C-4), this was approximately a six-fold increase. While not statistically significant, extracts obtained from the isthmus of hens within each environmental group appeared to have an inhibitory effect on glucose utilization by spermatozoa. The possibility of extracts containing cellular débris and/or bacteria which could bias the observed glucose utilization by spermatozoa was

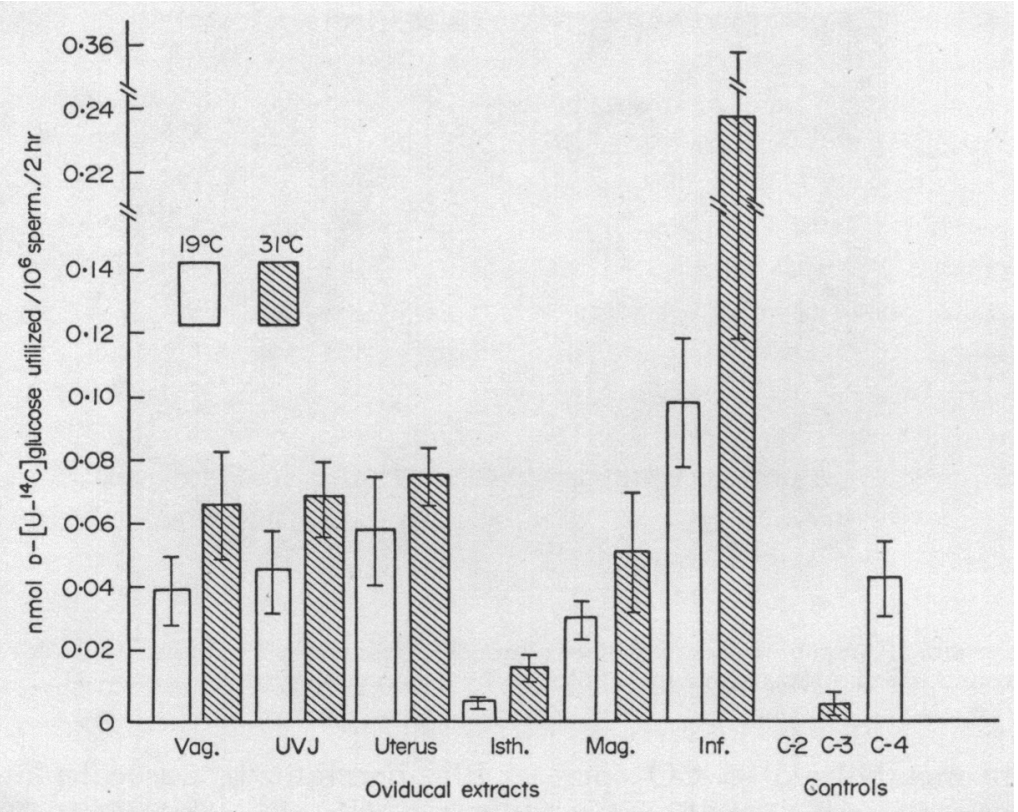

TEXT-FIG. 2. Glucose utilization by cock spermatozoa in the presence of various oviducal extracts (Vag. = vagina; UVJ = uterovaginal junction; Isth. $=$ isthmus; Mag. $=$ magnum; Inf. $=$ infundibulum) obtained from hens maintained at 19 and $31^{\circ} \mathrm{C}$. Vertical bars show the S.E.

not substantiated in the present investigation, since pooled extracts incubated in the absence of spermatozoa (C-2 and C-3) had little, if any, effect on glucose utilization.

\section{DISGUSSION}

Early work on the metabolism of fowl spermatozoa in vitro has been reviewed by Lorenz (1964) and indicates the ability of cock spermatozoa to derive energy from aerobic and anaerobic glycolysis. Nevo (1965) showed that 
aerobic conditions in the hen oviduct would be sufficient to support maximum sperm respiration and motility. Hamner \& Williams (1963) suspended cock spermatozoa in the magnum in vivo and found that afterwards the spermatozoa retained a twofold increase in oxygen uptake in vitro compared with controls that had not resided in the oviduct. Ogasawara \& Lorenz (1964), likewise, observed that extracts of the magnum stimulated respiration of fowl spermatozoa in vitro. In the present study, glucose utilization by cock spermatozoa was found to be significantly greater in the presence of extracts obtained from the infundibulum compared to all other extracts which were evaluated. A possible explanation for the apparent discrepancy in results may be due to the limited area of the magnum which was used to obtain extracts. Magnum extracts were obtained from the lower third of the magnum adjacent to the isthmus. It is quite possible that extracts from the upper two-thirds of the magnum adjacent to the infundibulum might enhance glucose utilization by spermatozoa to a greater degree than reported in this study.

Following ovulation, the ovum spends about $15 \mathrm{~min}$ in the infundibulum (Warren \& Scott, 1935) which has been established as the site of fertilization (Olsen \& Neher, 1948). It is logical to assume that the environment of the infundibulum would be a stimulatory one with regard to spermatozoa, preparing them for the act of fertilization. The observations of this study would certainly support this view.

Ogasawara \& Lorenz (1964) reported that extracts from the isthmus had no stimulatory effect on oxygen consumption by cock spermatozoa. Observations in this study actually indicate an inhibitory effect on glucose utilization by spermatozoa in the presence of extracts of the isthmus and, to a lesser extent, of the magnum. Litjens \& van der Horst (1972), in an investigation of the occurrence of amino acids and carbohydrates in the turkey oviduct, found rather large quantities of the protein, carboglutelin, in the magnum and isthmus. Carboglutelin is a hitherto unknown protein capable of forming a strong linkage with glucose and other carbohydrates with a straight chain (van der Horst, 1972). While carboglutelin has been shown to play a rôle in carbohydrate metabolism (van der Horst, 1972), its extent is unknown. It may serve as a transport medium in cells and/or assist in regulating the glucose content in various regions of the reproductive tract. If carboglutelin is also present in large quantities in the magnum and isthmus of the hen, its presence could explain the low glucose utilization by spermatozoa in extracts of this region of the oviduct. A portion of the radioactive glucose could have been bound by carboglutelin, thus making it unavailable for utilization by spermatozoa. The possible presence of carboglutelin in the hen's oviduct and its biological significance, however, require investigation.

The assumption made earlier that the decline in fertility of hens exposed to high environmental temperatures could be partly due to a defective oviducal environment which might be reflected in the metabolic activity of spermatozoa would appear from the results of this study to have some merit. Extracts from oviducts of hens maintained at $31^{\circ} \mathrm{C}$ consistently had a greater stimulatory effect on glucose utilization by cock spermatozoa than extracts from hens maintained at $19^{\circ} \mathrm{C}$. 


\section{REFERENGES}

Boone, M. A. \& Huston, T. M. (1963) The effects of high temperatures on semen production and fertility in the domestic fowl. Poult. Sci. 42, 670.

BUHLER, D. R. (1962) A simple scintillation counting technique for assaying ${ }^{14} \mathrm{CO}_{2}$ in a Warburg flask. Analyt. Biochem. 4, 413.

Burrows, W. H. \& Quin, J. P. (1937) Collection of spermatozoa from domestic fowl and turkey. Poult. Sci. 16, 19.

CLARK, C. E. \& SARAKOON, K. (1967) Influence of ambient temperature on reproductive tracts of male and female chickens. Poult. Sci. 46, 1093.

HAMNER, C. E. \& Williams, W. L. (1963) Effect of the female reproductive tract on sperm metabolism in the rabbit and fowl. F. Reprod. Fert. 5, 143.

Huston, T. M. \& CARMON, J. L. (1958) Influence of high environmental temperature on fertility and hatchability of eggs of domestic fowl. Physiol. Zoöl. 31, 232.

Litjens, J. B. \& VAN DER HoRst, G. J. G. (1972) Artificial insemination in turkeys and an investigation into a suitable diluent of turkey semen. Lijdschr. Diergeneesk. 97, 216.

Lorenz, F. W. (1964) Recent research on fertility and artificial insemination of domestic birds. Proc. 5 th Int. Congr. Anim. Reprod. $\mathcal{E}^{\circ}$ A.I., Trento, Section III, 7.

Martin, R. P. (1970) The effects of environmental temperature on the fertility of the male and female domestic fowl. M.S. thesis, Department of Poultry Science, University of Georgia.

Nevo, A. G. (1965) Dependence of sperm motility and respiration on oxygen concentration. J. Reprod. Fert. 9, 103.

Ogasawara, F. X. \& Lorenz, F. W. (1964) Respiratory rate of cock spermatozoa is affected by oviduct extracts. F. Reprod. Fert. 7, 281.

Orsen, M. W. \& NeHER, B. H. (1948) The site of fertilization in the domestic fowl. F. exp. Zool. 109, 355.

PARdeE, A. B. (1949) Measurement of oxygen uptake under controlled pressures of carbon dioxide. 7. biol. Chem. 179, 1085.

vaN DER Horst, G. J. G. (1972) Carboglutelin, an unknown protein, occurring in boar semen, spermatozoa and other cells, and its role in carbohydrate metabolism inside the cell. Cytobios, 5, 47.

Warren, D. G. \& Scott, H. M. (1935) The time factor in egg formation. Poult. Sci. 14, 195. 